\title{
Theory of the Gestapo
}

\section{by Aaron M. Zack}

\section{John Jay College and Baruch College}

azack@jjay.cuny.edu

Keywords: Gestapo; Secret Police; Totalitarianism; Nihilism; Surveillance; Technology

The modern problem of nihilism presaged the historical emergence, and presages the reemergence, of a Gestapo. Nihilism denotes a 'breakdown in the order of meaning', such that the nihilist cannot fully embrace transcendent truths, while simultaneously craving their certainty. ${ }^{1}$ The modern loss of Christian faith reintroduced the dilemma of nihilism, which had receded after its preliminary manifestation in the later Roman Empire. ${ }^{2}$ Thus, eventually, a Gestapo. Why so? Terror and propaganda appeared in the West with the French Revolution, whose mission was to eradicate the traditions and certainties of the old order: Christianity and the remnants of feudalism. In the West, worldly, utopian ideologies problematically filled the void left by the disappearance of Christian faith. Man, especially mass man as described by Ortega y Gasset, began to uneasily and unhappily worship himself and his extensions: the nation, state, class, race, party, or, increasingly, his own material and ideational consumption. ${ }^{3}$ As postulated, though, the essence of nihilism, to which the West has not yet found an answer, lies in the inability of the nihilist, perhaps especially those whom nihilism pains most, to fully believe in the worldly and therefore false utopia that he necessarily craves and embraces. Those who would embrace such utopias often, depending upon their nature, artificially and violently maintain them in the face of rival ideas, their own doubts, and the widespread nihilism that first engendered them. Along with nihilism and its 'antidotes', the terror and propaganda which first appeared in the West thus 
eventually spread, as far afield as Russia and East Asia. ${ }^{4}$ For the modern, totalitarian state, then, propaganda and terror, its primary tools, serve not only to directly reinforce the power of their wielders and deter action against the state, but also to (ultimately unsuccessfully) eradicate the nihilism which produced them. Thus, for a Gestapo- the decisive agent of terror in the totalitarian state- the ultimate target is not simply the actions of individuals who might threaten the state, but rather the minds and identity of those who doubt or reject the prevailing utopian ideology. The omniscient terror of a Gestapo attempts to mold the population in its innermost thought, ethos, belief and desire. Arising from nihilism, a Gestapo searches for its inner and outer reappearance, utilizing horror and torment in a futile attempt to vanquish it.

This essay will consider the genesis, development, methods and purpose of the Nazi Gestapo, and develop some broader theoretical conclusions from this historical analysis. It will then consider whether and how contemporary and emerging computational technology, combined with the degradation and decay of the liberal ideal and suffusing nihilism, might lead to the emergence of a specifically American Gestapo, which, should it occur, would, relatively effortlessly, surveil, comprehend, and penetrate the individual mind far more completely than could the old, relatively primitive, mid- 20th Century Gestapo.

\section{The Nazi Gestapo}

Genesis and Purpose: the Utopian Party and Absolute War

Neither the Prusso- German Empire nor the Weimar Republic had a national police force. Instead, police functions were reserved to the traditional Länder, which had preceded the central 
German state. Furthermore, both the Kaiserreich and Weimar Republic were Rechtstaaten: states governed by the rule of law, rather than an unrestrained party or dictator. The National Socialists, or Nazis, as a revolutionary, utopian, political party and movement, were intent upon overthrowing the Rechtstaat as a matter of ideology and precursor to their other goals. The Nazis focused upon the legal acquisition of police power as an important step in their consequent seizure of absolute power in Germany. Upon his legal appointment as Chancellor in January of 1933, Hitler, as the leader of a party which represented approximately $30 \%$ of German voters, insisted upon the appointment of Hermann Göring, his trusted confidant, as the interior minister of Prussia- the largest and most populous German Land. As such, Göring and the Nazis controlled the Prussian police, and utilized this power to suppress and terrorize their political opponents in Prussia. Prussia's police force and that of the other Länder were restrained by law, but their responsibilities included the defense of the Weimar Constitution and Republic against those who would destroy it, such as the National Socialists on the right and Communists on the left. The policemen that had been responsible for keeping watch on the Nazis were largely purged, but the political police responsible for surveilling and understanding the communists and other radical leftists were retained and utilized by their new political masters. The Nazis used the Prussian political police to better understand their leftist enemies, while the Prussian regular or uniformed police were ordered by Göring to stand aside as the Nazi private militia- the Stürmabteilung or SA-terrorized and intimidated the Nazis' enemies. The Prussian police did so and neither the judiciary or other elements of the crumbling Weimar state effectively opposed this extralegal, political violence. The SA created private, ad hoc prisons and detention centers where they tormented their victims, at this point almost entirely those of the organized political left, while in a more organized al- 
though still extralegal manner Himmler opened the first concentration camp under the control of the Schutzstaffel- or SS- and filled it with communists and other political opponents. ${ }^{5}$

Therefore, the concept or essence of the political proposed by Carl Schmitt, a German legal theorist of that time, appeared in its starkest form: not merely as the distinction between friend and opponent, but rather as the distinction between friend and enemy. ${ }^{6}$ The perverse genesis of the Third Reich (and its Gestapo) also reveal a truth deduced by Schmitt: the 20th Century wagers of totalitarian terror at home and revolutionary war abroad were not totalitarian states as such, but rather revolutionary parties, which captured the state and used it for their own purposes. ${ }^{7}$ Thus, according to Schmitt, revolutionary terror and war were waged by the Nazis, Bolsheviks, and Chinese Communist Party, rather than by the traditionally somewhat autonomous state structures themselves. The princely states of the ancien regime waged war against other princely states within Europe for territory, rather than against or for peoples, classes, or ideologies. Thus war was relatively bracketed, and followed a restrained Clausewitzian model of the state utilizing force against another states in order to achieve a quite limited political purpose. The French Revolution not only introduced revolutionary, ideological war to Europe as waged by the Jacobins, but also the wars of entire nations, as such less amenable to limited goals or bracketed methods. Given this shift away from limited political goals and hence bracketed war, the revolutionaries, logically, also introduced unrestrained terror and propaganda at home. With the rise of totalitarian, utopian parties in the 20th Century, the remaining brackets upon war were completely relinquished. As the party believed itself the agent ushering in a worldly utopia, the domestic and foreign enemies of the party, whether defined as a class, religion, nationality, etc., were perceived as absolute enemies requiring absolute subordination or destruction: a sentiment alien to the ancien 
regime and its ethos of restraint and law at home and limited war abroad. As the enemies of the totalitarian party were not states as such but rather peoples or groups both within and without, the brackets limiting war were necessarily and logically removed not only towards external enemies beyond the (archaic) formal borders controlled by the utopian party, but also towards the internal enemies within the state now in the grip of that party. Thus war was (and still is, for contemporary totalitarian parties) absolute and therefore no longer bracketed by sovereignty or formal state boundaries. The party waged total war against its internal as well as external enemies, varying its methods but with an identical goal and plan for the enemy: eradication or absolute submission to the party. ${ }^{8}$

Therefore the Nazi German Gestapo- an acronym denoting the Geheime Staatspolizei, or Secret State Police- ought not to be considered a police force, uniformed or not, as we understand such institutions in the (fading) liberal West. The Gestapo's essential function was not to enforce law or simply protect the security of the state as such. Rather, just as the Wehrmacht, Luftwaffe and Kriegsmarine were waging war against the external enemies of the Nazi party, so the Gestapo was waging an absolute war against the enemies of the party inside Germany, and, later, the areas conquered by the Nazis. Parenthetically, since revolutionary wars are waged by parties and their Gestapos, preliminary resistance ought not to focus primarily upon the state as such, but rather the party, and particularly a utopian- revolutionary (and therefore totalitarian) party.

As the revolutionary Nazi party's preeminent instrument of war within Germany, the Gestapo (and the SS, whose relations with it will be discussed) was, logically, unrestrained by law, custom, or any institution outside the party itself. If the true sovereign is 'he who decides on 
the exception' when normal law no longer applies, then Hitler, at the highest level, was the German sovereign after the Enabling Act and Night of the Long Knives. ${ }^{9}$ Within the broad parameters set by Hitler, however, the SS and Gestapo were the practical sovereigns in Germany, determining whether one was subject to normal law and hence under the purview of the judiciary, or an enemy of the party and/or their defined Volksgemeinschaft- 'people's community'- and therefore an object of absolute war rather than justice or law.

The Gestapo, in its own fashion, was waging a total war inside Germany. This leads us to the question of how Hitler and the party defined their enemies and utopian goals, which, in turn, determined whom the Gestapo would target and the methods utilized as it waged war on behalf of the party. For the Nazis, the object of utopian fantasy was neither a state, nation, class, or religion, but rather the Volksgemeinschaft: a somewhat actual, somewhat mythical, and, in cases of mixed blood, evidently nebulous racial community. For the Nazis, that which strengthened the racial community and its domination over other races was good, and that which threatened the health and dominant power of the racial community was a malady to be suppressed or destroyed. The purpose of the state was to safeguard, strengthen and ensure the domination and expansion of the racial community; all other considerations, such as Christian ethics, religion, or liberal concepts of individual rights and law, were considered as immaterial or positively harmful to the racial community, to be dispensed with. Whereas the state was considered a mechanical construction, managed and functioning according to rules appropriate to it, the racial community was considered a biological being, a living organism, capable of growth, health, and expansion, and susceptible to infection, decay and death. The Gestapo, according to this worldview, was the physician of that biological entity, responsible not only for suppressing or treating its diseases 
but also for preventing the emergence of disease and threats to its health. This explanation of Nazi ideology renders internally intelligible policies that, according to the Judeo- Christian morality which the Nazis rejected, were monstrous and otherwise incomprehensible: the mass murder of homosexuals, the mentally ill and physically handicapped of German blood, and the annihilation or enslavement of other races perceived as inferior or threatening to the integrity and supremacy of the German racial group. ${ }^{10}$

The organization of the Gestapo reflected the Nazi perception of the different types of threats to the health of the racial community. According to Hitler's thought, the Germans' most implacable and powerful enemy was the Jewish people- defined in (obviously problematic) racial rather than religious terms, and perceived as a dispersed, transnational racial community committed to its own supremacy and the degradation of all other racial communities. Since, according to the Nazis, the Jewish racial group's purpose was domination over other racial groups- i.e. a 'degraded' mirror image of the Nazis' aspirations for their own racial supremacy- seemingly incompatible or incoherent positions, such as identifying the Jewish enemy with the disintegrating effects of both capitalism and Bolshevism, begin to acquire an internal logic; these disintegrating, overtly opposed forces were simply varying expressions of the Jewish enemy's overall goal- the debilitation of their opponents' racial communities. Again, for Hitler, and, hence, the Gestapo, these concepts were understood in biological and organic terms, as a matter of competing life forms and the health or infection of physical bodies. Of Bolshevik Jews, Hitler declared: "No such inner value is attached to the number of Russian people that this number could endanger the freedom of the world. At least never (like the United States) in the sense of an economic and po- 
litical mastery of other parts of the globe, but at most in the sense of an inundation by disease bacilli which at the moment have their breeding ground in Russia."11

Significantly, though, the Gestapo not only had a sub- section assigned to Jewish matters, but also a broader office tasked with the persecution of both the Christian churches and the Jews: Amt IV B. As a universal moral system with Judaic origins, Christianity was an anathema to the Nazi ideology of zero- sum biological, racial struggle. According to Nazi doctrine, Christians, unlike Jews, were not a discrete race, and therefore those of German blood could be encouraged to relinquish their faith and embrace Nazi ideology. Similarly, communists, criminals and homosexuals of German blood were welcome to return to the racial community if they mended their ways and thereby strengthened it, unlike Jews, Slavs, and others of non- German blood who were biologically ineligible to join the utopian- racial group. However, German Christians such as Dietrich Bonhoeffer, who placed their faith and universal morality above the perceived demands of the racial community, were considered enemies of that community and Nazi party, and therefore targeted by the Gestapo. ${ }^{12}$

It is surely not a coincidence that many of the revolutionary, utopian parties- such as the Jacobins, Bolsheviks, Nazis, and Communist Chinese- determined that Christianity was a mortal enemy, and unleashed their terror and Gestapos against committed Christians. ${ }^{13}$ Why so? The revolutionary- utopian party, by its very nature, cannot accept any theoretical or actual limits on its power over and manipulation of humanity and nature. As the purpose of the party is utopian, an admission and acceptance of limits would deprive the party of its raison d'étre and the justification for its totalitarian power and atrocities. Christianity, however, considers man as sinful and his world as irremediably fallen- utopia, or salvation, is only possible in the hereafter. Therefore, 
unlike the partisan of the utopian party, the true Christian cannot worship (and therefore submit to) either the party or the chosen utopian group in whose name the party acts. As Ortega y Gasset implies, the faith of the self- worshiping totalitarian and that of the external or other- worshiping Christian are fundamentally incompatible. ${ }^{14}$ Then, too, as a follower of a universally applicable moral code which values all human life in itself, rather than viewing individual life as a disposable means to a worldly, utopian end, the devout Christian could not accept the Nazi doctrine of categorizing some life as unworthy of life. Therefore the Nazis planned to unleash their Gestapo upon Christianity in Germany, but considered that the opportune moment for a full offensive would only arise after the conclusion of the war. ${ }^{15}$

\section{The Gestapo and the State}

In the words of a Nazi ideologist, Werner Best, once consolidated under Himmler's control the Nazified police constituted "(...) the intersection of the movement and the state." 16 As the party's weapon against its internal, absolute enemies, the Gestapo, legitimized and organized on the level of the state, waged war against racial and ideological impediments to Nazi omnipotence and their planned racial- political utopia: communists, Jews, devout Christians, non- Aryans, and other Germans who threatened the health and power of the German racial community.

As the party-appointed physician for the German racially- defined body, the Gestapo was empowered to take preventive measures. That is, the Gestapo could detain, interrogate, torture, and/or send to a concentration camp Germans or aliens (with some exceptions) whom it believed threatened, or might threaten, the health of that body. On the other hand, members of the German 
racial community who committed or were suspected of committing 'ordinary' non- political crimes, such as fraud, for example, might never have any contact with the Gestapo or SS, and instead fall under the auspices of the normal criminal justice statutes. Therefore we might distinguish in Nazi Germany, as well as in other historical or emerging utopian- totalitarian states, two types of states, coexisting simultaneously and uneasily: the 'normative state' and 'prerogative state.' 17

For a liberal, the normative state is quite familiar and essentially encompasses the state as such: the elements and agents of the state are bound by law, rather than above it, and must follow rules which disallow certain methods and arbitrary acts. The written or overt genesis of the liberal, normative state can be traced back to the most important principle in the Magna Carta of 1215: the King (or, in modern parlance, the executive) is not above the law. In the Western liberal tradition, the only (for some) tolerable exception to the circumscribed, normative state occurs during a national security crisis or conflict with a foreign power; in these circumstances, on occasion, the prerogative state- unbound by overt or customary law- temporarily emerges to wield power against enemies, and then recedes once those enemies are defeated.

The prerogative state, in contrast, wields power without restriction by law or custom. Historians of the Gestapo have sought to distinguish between Nazi- German normative and prerogative states between 1933 and 1945, with the prerogative state encroaching upon ever more of the normative state's jurisdiction as time passed. This might, in fact, be a useful analytical division. However, a normative state which exists and functions at the whim of the prerogative state (i.e. to the extent the normative state is useful to the prerogative) is fundamentally different than and a pale shadow of the robust liberal, normative state, which only accepts prerogative state action 
outside the law under the most dire of circumstances (if then), and only temporarily, before reasserting its supremacy over the wielders of prerogative power. To claim, then, that robust normative and prerogative states might easily coexist is problematic. Once the Gestapo was empowered to take preventive action against any German without regard to law, then resistance to the whims of the Gestapo could only be considered by those with equivalent power within the prerogative state itself. The liberal- normative state, although it might adjudicate certain non- political crimes when committed by members of the racial community, had, as a robust reality, ceased to exist.

An emerging or actual Gestapo, then, is one symptom of an emerging or dominant prerogative state and the waning or defeat of the normative state and those who upheld it. Furthermore, a utopian- revolutionary party which captures the state will, sooner or later, either accept defeat, or create a Gestapo to carry out its prerogative designs. As the revolutionary party seeks to overturn the established order and its laws and customs, it cannot accept the restraints of the normative state, and therefore shifts towards and maximizes the powers of the prerogative elements within the state. However, by definition, the utopia- promised and asserted (and perhaps even believed in) by the revolutionary- cannot be achieved, but the power and unity of the party depends upon the assertion that utopia is plausible and forthcoming. Therefore the revolutionaryutopian party, to the extent it maintains itself as such, must eventually, in the face of an uncooperative reality, force the subjected population- object not only to submit, but also to assert the plausibility of the necessarily false utopian ideology. For this, a prerogative state and its attendant Gestapo are necessary. 
Parenthetically, the decay of the Roman Republic and emergence of a dictatorial- monarchical government also illuminates some of the tensions between normative and prerogative states. We can only touch upon this subject. Briefly, though, Roman law, which as a metaphor still suggests rigor and stability, continued to function at the sub- political level even as the Republic descended into factional strife and political anarchy. At the summit, though, the initially political and then violent conflict between, first, the optimates and populares, and then between individual condottiere such as Caesar and Pompey, consumed the restraints previously imposed by the collapsing normative state, which had successfully bracketed political conflict amongst the Romans for centuries. Unlike the 20th Century totalitarian states, in the consequent Roman dictatorial- monarchical state the normative and prerogative elements were able to coexist for centuries, although the Romans themselves yearned for a return to the fully normative early Republic. The final prerogative triumph at the sovereign- political level, did, predictably, require an attendant creation of a secret police, replete with informers, denunciations, arbitrary accusations, etc.. However, none of the Roman factions or individuals who struggled for supremacy- even the so-called populares- were utopian- revolutionary parties such as the Jacobins or Nazis. A modern utopian- revolutionary ideology was alien to the pragmatic Roman character. Therefore, once the monarchical- imperial dictatorship had been established, the Roman prerogative state limited itself to defeating overt rebellion or conspiracy within a small elite, and had no need to encroach upon, shape, and therefore terrorize the population at large. After the establishment of the principate and end of the Republic's civil wars, for the mass of Romans the normative state continued to provide durable law and stability- and this, among other factors, allowed the Roman state to endure for another four centuries. ${ }^{18}$ 
Methods: Surveillance, Torture, and Isolation

Once the Nazi party defined its enemies, conquered the state and subordinated it, the Gestapo's primary tasks were to identify and disrupt actual and potential networks of resistance against the party and its dominance within the state. Individuals, too, who might present a threat, or resist, often drew the attention of the Gestapo. As a corollary to or consequence of the Gestapo's efficient surveillance and penetration of ideological or other resisters, a widespread fear pervaded German society, increasing in severity and effect as the Nazi party's powers suffused throughout the waning civil society and autonomous state. Consequently, although the Gestapo never numbered more than approximately 6,500 employees assigned to the Reich itself, the fear inspired by their apparent omniscience and formidable economy of force engendered a prevailing and pronounced isolation amongst a previously social society- a common, dystopian consequence of the totalitarian- utopian enterprise. The end- stage of the Gestapo's perceived omniscience and associated terror was that of a multitude of separate, isolated, atomized individuals in the face of and subservient to an all- powerful, omniscient state, unmediated by robust, autonomous institutions such as the church, union, corporation, or family. There existed, as a psychological matter, only the state and the naked individual, cut off, by fear, from all intimacy except that approved by the party and its state. All Germans, at the mercy of the Gestapo, were subject to potential interrogation, physical torture, and internment in the concentration camps, without recourse to law or alternative institutions that might protect them. ${ }^{19}$ Thus prevailing terror created and determined a prevailing individual isolation- which Dante, in the Inferno, re- 
served for some of the lower circles of hell and heinous individuals, suggesting that mere physical torment alone might, ultimately, be less painful than prolonged isolation. As a broad proposition, then, ironically, and perhaps predictably, the physician tasked with preventing and defeating threats to the health of the coherent, unified racial community instead, through its efficiency and terror, fragmented it into isolated individuals unable to fully exist and truly bond- that is, the physician to the racial community shaped a population of half persons, incapable of the full range of human activity and existence.

How, specifically, did the Gestapo achieve this? As noted, the Gestapo, unlike the domestic security services in liberal- legalistic states, was unrestrained by law and did not accept the impediments imposed by due process, habeas corpus, warrants, an independent judiciary, etc.. As they absorbed and reshaped the Weimar police forces, the Nazis coopted political police investigators with excellent forensic and investigative skills. Many of these joined the Gestapo, such that its investigative and forensic capabilities were efficient and formidable. The support of a significant percentage of the German population was also crucial to the perception of Gestapo omniscience. Block wardens were organized and deputized throughout Germany, responsible for reporting to the authorities, who might refer the matter to the Gestapo, suspicious behavior, a chance remark, joke, or statement (particularly once the war began) which might undermine morale. Children, encompassed within an ideological system of education and Nazi youth organizations, were encouraged to denounce their parents if the latter spoke against the party and its utopian vision. For those who opposed the party, then, the safest course was to retreat into isolation and silence. 
If the Gestapo received a report about suspicious or problematic behavior, it might simply issue a warning to those reported, and threaten more severe consequences in the event of a further offense. Or the Gestapo might attempt to 'turn' the subject to inform upon her fellow travelers, in order to comprehend and roll up networks of resistance. These attempts to turn individuals and understand the scope of a network sometimes required persuasion or threats alone to harm the target and their families. However, if persuasion was ineffective, or in order to ensure that the detained individual volunteered all of his important information, the Gestapo could utilize torture. The severity and duration of the torture, might, depending upon the subject, be regulated by a medical observer, but in other cases, typically involving victims outside the scope of the racial community or Germans deemed a severe threat to the party, the Gestapo could utilize torment without limit. Finally, the Gestapo could release detainees (who might now inform on their networks), refer them to the normative criminal justice system, send them to a concentration camp, or order them executed- at the Gestapo's discretion. ${ }^{20}$

The Gestapo itself did not operate concentration camps or wield power within them. However, after control of the German police was transferred from Göring to Himmler in 1934, the Gestapo was incorporated into Himmler's budding internal security empire, which eventually encompassed all the Nazi Party and state organs of terror and suppression. The Gestapo fell under the auspices of the Reichssicherheitshauptamt- the RSHA- led by Reinhardt Heydrich, essentially Himmler's deputy and the second most powerful man within the SS and security services. As noted, the German normative criminal police also fell under the control of the overtly prerogative Himmler, as did the SS's own intelligence service- the Sicherheitsdienst- and the concentration camp system, controlled by the SS. Therefore the Gestapo could draw upon and coordi- 
nate with both the putatively normative criminal police as well as the other institutions of terror, all organized under the RSHA and controlled, directly or indirectly, by Himmler and his deputies, who, in turn, answered to Hitler in his role as leader of the party and the attendant and largely assimilated German state. Within this constellation, the Gestapo remained the decisive instrument which dominated the German population, hunting for asocial subversives, hidden Jews, and other enemies throughout Germany. ${ }^{21}$

\section{Results and Limitations}

The Gestapo, with its efficiency, power, resources, and coordination with the rest of the security state, achieved impressive results, but also failed on significant occasions. The first target was the KPD- the German Communist Party. After the initial wave of arrests in 1933 and incarceration of KPD leaders in extra- judicial prisons and the first Lager (concentration camp), Dachau, the remaining communist networks were quickly penetrated and rolled up. For the remainder of the Third Reich, neither the KPD or other organized left- wing or labor movements were able to challenge the Nazi Party, organize effective resistance to its policies, or even significantly impede war preparations and production. Rather quickly, the Gestapo ensured that organized resistance, if significant, would require action by elements inside or associated with the prerogative state, such as the traditional- conservative military officers, whom Hitler, despite the creation, expansion, and preferential treatment of the combat or Waffen SS, could not dispense with. ${ }^{22}$ 
Organized Christianity, with some notable exceptions, largely attempted to reach a modus vivendi with the avowedly anti- Christian, neo- pagan Nazis. The Catholic Church, viewed since the formation of the Prussian- Protestant dominated Second Reich as a particularly problematic political actor, was partially neutralized by Germany's concordat with the Vatican in 1933, although the Nazis exerted further pressure as the party tightened its grip on society. The Protestant, and particularly Lutheran, denominations had a long tradition of subservience to the German state. Individual churchmen such as the Protestant pastor Dietrich Bonhoeffer spoke out against Nazi racial persecution, hostility to Christianity, and actions against German 'life unworthy of life', such as the euthanasia of the mentally ill and physically handicapped. Elements within the Catholic Church also made efforts to shield 'racial' Jews, defined as such by the Nuremberg Laws, who had been baptized or converted to Catholicism. The Gestapo, ever mindful of public morale given the perceived German internal collapse at the dénouement of the First World War, was also careful not to move too swiftly against full or partial 'racial' Jews married to nonJewish Germans, and protests by such Germans against the arrest of their Jewish spouses led to their release. Similarly, the security services retreated after initially removing crucifixes from Bavarian schoolrooms. Reports of this action had reached soldiers on the Eastern front. This damaged morale and undermined the argument that the war in the East was necessary to defend European, Christian civilization from godless Bolshevism.23

Therefore, when dealing with institutions, populations, or beliefs widely supported by the German people, the Nazis and Gestapo were careful not to act too precipitously or prematurely, since they valued high levels of public support and morale, particularly once the war began. However, the Gestapo and their confederates were quite effective in crushing individuals, such as 
Bonhoeffer, who overtly challenged the party, and identified, rounded up, and handed off to the Lager system groups such as Jehovah's Witnesses, committed communists, and Jewish Germans without ties to Aryan Germans who might seek to protect them. By March 1943, for example, about 5000- 7000 Jewish Germans remained in Berlin, attempting to evade the dragnet. Hunted by the Gestapo, who were sometimes assisted by Jews turned through threats of torture and the usually false promise of lenient treatment, the remaining Jews, without money, ration cards, work, or access to food and shelter, could not survive without assistance from non- Jewish Germans, who thereby risked their own lives and often those of their families. By the end of the war, 1400 of the Jews in Berlin had managed to evade the Gestapo and survive. ${ }^{24}$

The Gestapo experienced some significant failures as well. In addition to the limitations self-imposed by sensitivity to German morale, which were discarded when faced with overt challenges to the party's power, the Nazis perceived the necessity of cooperating with the army- now known as the Wehrmacht- in pursuit of European supremacy and global power. ${ }^{25}$ Over time, Hitler designated the Waffen SS, which reported to Himmler, as the recipient of the finest weaponry for the land forces, and many of the finest recruits also joined the SS combat units. ${ }^{26}$ However, when the Nazis initially assumed a dominant position in the state, Hitler considered that only the army, despite the traditional- conservative ethos of the majority of the officer corps, could serve as the party's instrument in the inevitable clash with foreign powers. Therefore Hitler was unwilling to countenance Ernst Röhm's insistence that the SA- the Party's military wing during its struggles in the Weimar period- should, with its Nazi- revolutionary credentials and reliability, supplant the traditionalist army as the decisive instrument for war against opposing states. Killing two birds with one stone, Hitler decapitated the SA's leadership in the Night of the Long 
Knives in 1934. He removed the last challenge to his dominance within the party, and won the army over to his political leadership by deceptively pledging that it alone would bear weapons against Germany's foreign enemies. Through a subsequent series of exploited scandals and soft purges limited to the very top of the army's leadership, Hitler moved towards domination over the upper echelon of the officer corps- a domination which waxed with time and eventually extended, despite the officer corps' obstruction and complaints, to a military- strategic and operational control over the conduct of the war. ${ }^{27}$ Nonetheless, unlike Stalin in the 1930 s, Hitler was unwilling or felt unable, until the assassination attempt of July 1944, to broadly move against the higher officer corps and violently purge or decapitate it. Therefore it, for a time, retained some of its status as a semiautonomous actor- armed, with its own loyalties, ethos and traditions incompatible with those of the revolutionary- utopian Nazis, yet bound by those traditions to serve the German state, of whom Hitler was the legal as well as de facto leader. Thus, unlike the communists, whom the Gestapo was unleashed upon without restraint, or the churches, outside the state and only protected by public opinion, the officer corps and Wehrmacht retained some insulation from the Gestapo's and party's insistence upon dominating all aspects of German society, and also necessarily retained its arms and (supervised) access to Hitler. Therefore while the Gestapo wreaked a terrible vengeance after the 1944 attempt on Hitler's life, the relatively closed caste of the officer corps came quite close to assassinating Hitler on this as well as a number of earlier occasions, despite his formidable personal security precautions. ${ }^{28}$

In addition to the challenge posed by the relatively opaque, inchoate army network, the Gestapo also had difficulty preventing acts of violence against the party by individuals acting on their own- in contemporary parlance, 'lone wolves'. Such acts which rose to the level of signifi- 
cance were rare. But the perpetrators' lack of connection to a surveilled or suspected network neutralized many of the Gestapo's advantages, such as its reliance upon turned informers or the reports of suspicious citizens. In such circumstances, the Gestapo could only attempt to apprehend the perpetrator after the act, and determine whether she was in fact a lone actor, or, instead, a member of a network. With war approaching, the elements within the state with some strength to decisively act, such as the higher echelon in the Wehrmacht, failed to do so, as did the residual organized communists and anti- Nazi Christians. However, a lone wolf, George Elser, a pipe fitter with communist sympathies and a moral opposition to Nazism, but no history of organized communist or anti- Nazi activity, nearly succeeded in assassinating Hitler. The incident reveals the limits of the mid- 20th Century Gestapo. Elser, without communicating his intentions to anyone else, walked into the Munich beer hall cellar where Hitler was due to speak, as he always did, on the anniversary of the failed putsch of 1924. Impersonating one of the workers preparing for the appearance, Elser fitted a timed bomb in a pipe near Hitler's podium. The bomb exploded as planned, but Hitler survived since he had left the cellar 15 minutes ahead of schedule. Elser was detained by suspicious border guards as he attempted to cross into Switzerland. He confessed to the attempt, but was interrogated and tortured by the Gestapo at length, who found it difficult to believe that he acted without the assistance of a network. ${ }^{29}$

\section{Preliminary Theoretical Conclusions: 'Mass Man' and the Rise of the Gestapo}

In 1930, the Spanish philosopher Jose Ortega y Gasset theorized the rise of 'mass man' and his opposition to 'noble man.' Despite the archaic and somewhat problematic connotations 
of these terms, the concepts they represent are useful in our analysis of the rise of the Gestapo. 'Mass' and 'noble' man are not associated with social or political classes, but rather psychological types (which encompass women as well.) Mass men exist amongst the upper classes, and noble men amongst the laborers. First appearing in the later Roman Empire and reappearing in the early 20th Century, the minds of mass men emerge from a state of material abundance and security perceived as given, normal, and natural, but which is necessarily created, precarious, and contingent. Mass man therefore believes that all is possible and subject to his power; nothing can or ought to restrict his power, appetite, worship of and regard for himself. He is incapable of and uninterested in subordinating his own lust for power to any ethos external to his own desires. ${ }^{30}$

The preeminent agent of mass man, through which he intends to subordinate reality to his purpose, is the state. ${ }^{31}$ The state is thus an intermediate object of worship- the ultimate object of worship being mass man himself- and terror is necessary to force obstacles to power and desire to either submit to the state, or face liquidation. Propaganda is not only necessary to mobilize power and dissuade opposition to the worshiped state, and not only to form or maintain the identity of mass man; rather, propaganda reassures the mass men that they are, in fact, all- powerful and worthy of self- worship, that all is possible with full surrender of autonomy to the godlike state which will act to fulfill their utopian, unlimited (and therefore necessarily insane) desires. Thus the essential characteristic of both mass man and his chosen instrument, the state, is the refusal to submit: to a moral code, God, or nature. The concepts of necessity and limit and, consequently, some type of submission or acceptance, cannot be admitted by mass man. The prime and mortal enemies of mass man and his state, therefore, are truth, ethics, religion, and their representatives: those who devote themselves and submit to these outside constraints, not considering 
them an affront to their dignity, but rather a necessary impetus to a worthy life mission. Thus, for mass man to fully triumph, both the affront that noble man presents and the barriers constructed to limit state power must be destroyed. That is, as mass man, to realize his insatiable, never- ending desire to view himself as all- powerful and without limit, cannot accept limits on himself psychologically and the state in reality, or even an asserted justification of a submission to limits, noble man and the truth which he submits to are necessarily enemies, which much be destroyed or crushed. Mass man and his state and noble man and her culture are necessarily in opposition and cannot comfortably coexist. Or, rather, noble men might observe and detach from mass man, but mass man and his state cannot detach from and accept noble man and her example. To paraphrase Trotsky: noble men may not be interested in war with mass man, but mass man and his agents are necessarily, sooner or later, interested in war with noble man.

Thus to enforce mass man's will, a Gestapo must degrade or destroy noble man, and degrade, destroy or pervert that which noble man wholeheartedly devotes herself to, and which mass man passionately hates as an affront to his own omnipotence: truth and the devotion to an ideal outside or above her own desires. The Gestapo is necessary to enforce obedience to the agent of mass man, the state. It is necessary as a tool of power unlimited by the restraint of law, which mass man cannot accept as a matter of disposition and principal. Thus, as an expression of mass man and his state- agent, the utopian- totalitarian Gestapo transforms itself from a means of exerting power to an end of wielding power as an affirmation of mass man's absolute triumph- or so he thinks. For, of course, ironically and predictably, mass man's Gestapo eventually enslaves him and reveals his self- regard and omnipotent fantasies as degraded and farcical. The Gestapo thus represents both the hubris of mass man, supposedly ascendant, and the nemesis that follows 
from his insatiable self- regard. If America, then, is descending into the triumph and rule of mass man, a land where the limits to power and consumption set by reality and nature are dismissed, a peculiarly and particularly American Gestapo must eventually emerge, for mass man cannot triumph and exist without it.

\section{The State's Expanding Computational- Surveillance Power}

The Virtual World and Observable Data

Expanding computational capacity has created an unprecedented capacity for both active and passive surveillance by an unrestrained state of its population. Moore postulated that the computing capacity of the single microchip would double every two years, and, so far, this has proved to be the case. A contemporary Apple smartphone, therefore, has greater computational power than an IBM mainframe computer in 1950, and the implications of this development, and its future consequences, are not yet fully understood. The associated and continuing development of drones, optics, nanotechnology, biotechnology, and artificial intelligence are likely to further enhance surveillance and manipulative technologies in both predictable and unpredictable ways. The old Gestapo focused on surveilling, understanding, and terrorizing networks and groups, denoted by the party, which threatened the power of the racial community. The people were subjected to the Gestapo's active efforts to identify, penetrate, turn and terrorize enemies, as well as continual 'passive' surveillance by motivated individuals. This Gestapo's efficiency was limited by its manpower and the labor- intensive requirements of certain surveillance operations, and depended upon the broader support of informers, block wardens, and the rest of the security ap- 
paratus. Even so, despite the limited technology at its disposal, the Gestapo's capacity to both detect and destroy networks, and to intimidate, terrorize and therefore isolate individual Germans, was formidable.

However, as our intellectual, social, political, commercial and other activities have migrated to the virtual world of computers and their networks, expanded and growing opportunities for surveillance and detection- particularly passive surveillance- are less and less constrained by the limited manpower of the security services or support of the population; and the 'internet of things' will extend much of the already 'surveillable' activities of the virtual world into the real world as well, rendering them increasingly indistinguishable.

The precondition for surveillance is, logically speaking, the occurrence of some activity that can be observed. As electronic machines which operate and communicate through the use and manipulation of electronic symbols and actions, every action of a computer, and, therefore, networks of computers, generates trails of observable and recordable data. To quote Bruce Schneier, a cyber security expert and scholar, "Computers constantly produce data. It's their input and output, but it's also a product of everything they do. In the normal course of their operations, computers constantly document what they're doing."32 Therefore all computational and virtual activities are, theoretically, objects of potential observation and interpretation- and such data, if recorded, can be stored forever (practically speaking)- unerasable, unforgotten, and available for future exploitation. Thus, perhaps, the logic of the United States National Security Agency's bulk collection of the metadata of phone calls made within the past six years, and its construction of massive data collection centers in the American southwest. ${ }^{33}$ 
To the extent the state can penetrate any computer, and the networks they form, then, given the pattern of contemporary modern activity, the old manpower and other constraints on intensive surveillance are increasingly irrelevant. The typical American generates data with every text, phone call, mailed letter, ATM transaction, credit card purchase, web search and visit, library book checked out, etc.. All this information can be collected by the state, without a court order, through bulk collection practices or national security letters. For example, the US courts have found that one has no expectation of privacy regarding the outside, rather than the internal contents, of mailed packages and letters. Therefore while the authorities require a specific warrant to open and read a sealed letter (and, similarly, to record the contents of a phone call), no such warrant is necessary to scan and record the outside of a letter or package. Letters and packages mailed within the United States are scanned and, therefore, every sender's return address and the recipient's address are recorded and stored in government databases. The looming extension of the internet of things suggests that further recordable data will be generated when we lock and unlock our doors, turn on and off the lights, drive, open the refrigerator, etc... ${ }^{34}$

But of what import, we might ask, is much of this data, and particularly 'metadata'- that is, the data which reveals who mailed, called, or texted whom, without revealing the content of those communications? If the state requires a warrant to examine the actual content of a letter, email, text, or call, and if such contents might be encrypted such that the state cannot penetrate it, will not privacy exist despite meta and other data generated without any expectation of privacy, and therefore collectible without warrant? Our historical and theoretical analysis of the Gestapo suggests that an emerging revolutionary- utopian party would not allow custom or law to restrain 
its Gestapo tasked with wielding the forces of surveillance, penetration and terror to advance the party's power and its utopian program. A Gestapo will exploit collectible data.

\section{Encryption}

The history of internal and external absolute war suggests that the revolutionary party and its state, in response to private attempts to limit its reach, will not simply abandon the field and allow advanced encryption methods to shield significant amounts of exploitable data. For example, even the US State Department, an institution of a liberal- legal order, classified encryption technologies and techniques as munitions, thereby prohibiting their export. ${ }^{35}$ The NSA and Federal Bureau of Investigation have repeatedly either coopted private technology and telecommunications corporations, such that encryption keys or back doors were available to the state, or, through hacking or direct physical penetration of networks, ensured that they can defeat any attempted encryption or anonymization measures: "The goal of the NSA's surveillance is neatly captured by quotes from its top-secret presentations: 'collect it all,' 'know it all,' and 'exploit it all."'36 A utopian- totalitarian party in control of the state would not allow its subjects to utilize effective encryption tools. Even many liberal and quasi- liberal states are leery about undefeatable encryption. The domestic targets of a potential Gestapo, then, would most likely require access to encryption technologies produced and distributed outside the grip of their ruling partystate, which would presumably criminalize and actively seek out such use. Between technologically advanced powers, then, a classic arms race pitting defensive and offensive cyber technologies is likely to intensify, without regard to treaty or proposed international supervision. Within 
states, only the most dedicated liberal orders which perceive themselves safe from both internal and external attack (and these are unlikely to exist) would allow foreign actors or intrepid individuals to introduce and deploy unbreakable encryption without resistance. Thus the state will likely maintain access to vast troves of data about its population (and those of other states), unless the state subjects itself to legal restraint. The question remains, then, for the prospect of the remnants of privacy in the United States: will the state (and its dominant political parties) likely restrain itself?

\section{Data Correlation}

Correlation presents another method for exploiting the exponentially increasing amounts of open and encrypted data, in the service of surveilling both individuals and networks. ${ }^{37}$ The general public probably underestimates or is unaware of data correlation's potential to reveal identities, interests, beliefs, relationships, and networks. This might be accomplished by an active, targeted investigation requiring manpower, but not any actual physical surveillance. Or, ominously, correlation might be conducted by passive, previously programmed algorithms (and, in the future, artificial intelligence) without the need for either physical surveillance or human activity and its associated manpower requirements and limitations.

Let us consider, for example, the investigative potential of coordinating an individual's mobile phone location (known from Global Positioning System and other generated data) with additional data points. Assume an individual wishes to place a phone call, not necessarily anonymous to the recipient, but with the metadata linking him to the recipient shielded 
from the state. An (increasingly archaic) public pay phone is used to place the call. But if the individual placing the call left his own mobile phone on and carried it, his GPS coordinates could be used to determine that he placed the 'anonymous call', thus revealing his relationship to the recipient. Or perhaps the individual turned his mobile phone off. Video camera recordings- increasingly prevalent- might be scanned by algorithms, linked with databases storing every picture ever posted to the internet, scanned by facial recognition software, and used to identify the caller. Or perhaps, in the future, algorithms will scan the voiceprint of every voice call made in the United States, and determine whether any of those calls were made by an individual of interest to the state or ruling party. Video cameras are currently placed within every post office. Might every external mailbox, as well, fall within the purview of a camera, thereby providing the state, armed with databases, algorithms, watch lists, and facial recognition technology, with the means to identity anyone who mails a letter at a particular time and place?

Active and Passive Surveillance

To be sure, we might imagine effective countermeasures taken to defeat such surveillance. However, for not only the typical citizen, but also those in some fear of the state, such efforts are currently prohibitively difficult. Our default behavior so far has been, typically, to acquiesce to rather pervasive passive surveillance; 'passive' in the sense that the state isn't actively interested in watching us, but rather that it and the corporations cooperating with it are passively accumulating data, which reveals our political opinions, habits, friendships, romantic relationships, interests, physical movements, networks, finances, and medical concerns, and storing such 
data indefinitely in case future exploitation is desired. ${ }^{38}$ The state, should we attract its attention, could sort through and evaluate this passively acquired data- which in the 1940s the Gestapo would have had to expend effort and manpower accumulating- and peer into our souls.

A recent event illuminates the potential of data gathering when surveillance shifts from the passive to the active. The FBI received information that the then- director of the US Central Intelligence Agency, David Petraeus, was possibly compromised by a romantic liaison, and that he had possibly leaked classified information to this interest. The CIA director had been receiving emails from Paula Broadwell, a journalist, at his personal account, which she had sent from an anonymous account. How did the FBI link Broadwell to the anonymous email account? It had been accessed through various hotel Wi-Fi networks. The FBI correlated the guest lists of the hotels at the times the emails were sent with those people known to have had some connection to the CIA director. As a result, Broadwell was identified as a subject of interest, and eventually Petraeus was forced to resign and plead guilty to providing her with classified information. ${ }^{39}$ How did the FBI determine that Broadwell had been a guest at the hotels on the specified dates when the emails were sent? That detail has not been released publicly. However, a US government agency- the Consumer Financial Protection Bureau- maintains a database which records and stores the details of most credit card transactions conducted within the United States. ${ }^{40}$ Presumably mining such data for transaction patterns would not be too difficult.

For such reasons, in addition to encrypting communications, those concerned with avoiding state surveillance have developed techniques and methods to mask their activities. As noted, the state monitors credit card transactions. It also monitors cash deposits or withdrawals of $\$ 10,000$ or more- and attempts to evade the reporting requirement by deliberately depositing or 
withdrawing cash below the reportable limit counts as structuring, a federal crime. There have recently been proposals by economists and journalist to do away with cash altogether- primarily to give the state greater control over monetary stimulation, but which would also result in a further erosion of privacy and greater state surveillance capacity. Unlike twenty years ago, for example, today it is quite difficult, although not impossible, to purchase a book without generating identifying data which is passively recorded. If a credit card were to be used, the Consumer Financial Protection Bureau would likely record the transaction and store it in its databases, available for current and future correlation with other data of interest to the state. If cash were to be used, the purchase would require correlation with other data such as bookstore surveillance camera recordings, cell phone location data, etc., in order to attempt to determine which individuals purchased, for example, copies of the Koran in a particular city or state. If cash were illegal, or the majority of reading material only accessible electronically, or the 'internet of things' extended to physical books and other objects, simply reading a book with true anonymity and privacy would be even more difficult.

\section{Conclusion}

The question presents itself: is America descending into both nihilism and the triumph of mass man, such that a utopian party- state and its omniscient Gestapo will necessarily seek out and destroy those who devote themselves to truth, autonomy and morality? As we have defined and utilized these concepts, the nihilist and mass man both require a Gestapo, although the two types are distinct and therefore embrace terror for different reasons. Mass man worships himself, 
and wields the Gestapo against those who would oppose his desires as well as the very image of omnipotence that determines his identity. The nihilist craves truth and meaning outside of himself, but cannot easily accept that these exist: thus beliefs are asserted which propose utopian, transcendent truths, and the Gestapo must destroy the doubt which sowed the seeds of the asserted, false, utopian proposition. Although the nihilist, in this sense, remains a step removed from the unquestioned self- regard of mass man, both are united in asserting that none can oppose in thought or deed the worldly objects of their troubled admiration and worship.

Mario Vargas Llosa, the Spanish novelist, asserts the 'death of culture' in the contemporary West. He reviews interpretations of the concept of culture by the major western intellectuals after the Second World War. Essentially, Vargas Llosa charts a degradation of culture as a concept, and this degradation advanced in tandem with the disappearance of culture itself. From a concept associated with standards, discipline and refinement, accessible only to the elite and a necessarily select group of individuals, the concept of culture was appropriated, diluted, extended, and deconstructed, until the distinction, conceptually and in reality, between culture and nonculture, or barbarism, lost all meaning. Therefore culture itself, rather than spreading to the masses, has simply and tragically disappeared. ${ }^{41}$ Without utilizing these concepts and terms, what Vargas Llosa has described in the cultural sphere is, in fact, the triumph of nihilism and mass man.

According to Vargas Llosa, culture has been displaced by the dominant ethos of our current, Western civilization: 'the society of the spectacle'. Within this society, the virtual world of the Internet, television and film shapes our identity, belief and desire, far more so than the comparatively boring, disappointing and complex 'real' world. Increasingly dominant, the highest 
good of this virtual world is its provision of constant stimulation and entertainment, which take precedence over the substance and importance of true political, religious, ethical, and cultural life. ${ }^{42}$ Thus formerly autonomous, cultured citizens have now been replaced by hollow consumers of spectacles, whose addiction to entertainment is similar to, but far more pervasive than, that of the crowds in the ancient Roman Coliseum. And political life, and the state itself, are increasingly subsumed within the realm of the virtual spectacle.

If Vargas Llosa is correct, then we ought to modify Ortega y Gasset's analysis, as well as those of the Western analysts of nihilism. We are now presented with a particular sort of mass man and nihilist: consumers of virtual spectacles, whose self- worship and utopian ideology are intimately linked with the production, digital manipulation, and computer- generated dissemination of entertainment which reinforce their self- worship and fantasy. Therefore the concept of the 'society of the spectacle' links the rise of nihilism and mass man with the new world of data and images generated, modified and observed by computers, and those who control them.

The American ethos of materialism was initially leavened by Christian ethics and their derived liberal ideal: the dignity (and consequent autonomy) of the individual. This dignity was quite different than mass man's self- worship, or the nihilist's utopian fantasies. Now, though, we in the West see the waning of all missions external to self- worship or utopian fantasy. Insatiable consumption of the material world, fantastical ideas and images takes precedence over all other considerations, whether internal or external. Those who would oppose or even object to the prevailing consumption of ideology and fantasy cannot expect to remain unmolested. In the words of Irving Babbitt, a scholar of Buddhism: "A world of frenzied producers requires as its complement a world of frenzied consumers...The current notion that it is possible to establish a collec- 
tive peace and brotherhood among men who are individually filled with every manner of restlessness...(seems) delirious." 43 Of the two- the material and the fantastical/ ideational- the ever expanding consumption of the latter is the decisive element in the emerging American 'spirit'. At this point, then, the nihilist and mass man intersect: neither can tolerate a rupture or interruption of this consumption and the fantasies it supports. And, should a Gestapo emerge to defend their consumption, technology will empower that Gestapo to reshape its obstructions far more thoroughly than did its totalitarian antecedents in the 20th century.

\section{Notes}

${ }^{1}$ Simon Critchley, Continental philosophy: a very short introduction (Oxford: Oxford University Press, 2001), 80 4.

2 Jose Ortega y Gasset, The Revolt of the Masses (New York: W. W. Norton, 1932), 19.

${ }^{3}$ Ortega y Gasset (see note 1 above), 55 - 60. Irving Babbitt, The Dhammapada: Translated from the Pali with an Essay on Buddha and the Occident (New York: New Directions Books, 1936), 110.

${ }^{4}$ Ludwig Dehio, The precarious balance: four centuries of the European power struggle (New York: Knopf, 1962), 138.

5 Joseph Bendersky, A history of Nazi Germany, 2nd Edition (Chicago: Burnham Inc. Publishers, 2000), 101 - 10. Carsten Dams and Michael Stolle, The Gestapo: Power and Terror in the Third Reich (Oxford: Oxford University Press, 2014), 1 - 10. Ian Kershaw, Hitler, 1889 - 1936: Hubris (London: Penguin Group, 1998), 420 - 21, 454 - 56. ${ }^{6}$ Carl Schmitt, The Concept of the Political (Chicago: The University of Chicago Press, (1932), 1996), 26.

${ }^{7}$ Carl Schmitt, Theory of the Partisan: Intermediate Commentary on the Concept of the Political (New York: Telos Press Publishing, 2007), 15.

8 Ibid, 49 - 54.

${ }^{9}$ Carl Schmitt, Political Theology: Four Chapters on the Concept of Sovereignty (Cambridge: The MIT Press, 1985), 5 .

${ }_{10}$ Bendersky (see note 5 above), 24 - 6, 33 - 8. Dams and Stolle (see note 5 above), 29 - 33. Robert Gerwarth, Hitler's hangman: the life of Heydrich (New Haven: Yale University Press, 2011), 58 - 9. Peter Longerich, Heinrich Himmler (Oxford: Oxford University Press, 2012), 261 - 279.

${ }^{11}$ Andreas Hillgruber, Germany and the Two World Wars (Cambridge: Harvard University Press, 1981), 51. 
12 Dams and Stolle (see note 5 above), 20.

${ }^{13}$ Gerwarth (see note 10 above), 101 - 107. Longerich (see note 10 above), 218 - 225. Donald Rayfield, Stalin and His Hangmen; An Authoritative Portrait of a Tyrant and Those Who Served Him (London: Penguin Group, 2004), $119-23$.

14 Ortega y Gasset (see note 1 above), 62 - 3.

${ }^{15}$ Dams and Stolle (see note 5 above), 98 - 102. R. J. Overy, The dictators: Hitler's Germany and Stalin's Russia (London: Allen Lane, 2004), 278 - 86.

16 Dams and Stolle (see note 5 above), 16.

${ }^{17}$ Ibid, xiii.

18 Mikhail Rostovtzeff, Rome (Oxford: Oxford University Press, 1960), 175 - 9, 194 - 8, 228 - 30.

${ }^{19}$ Dams and Stolle (see note 5 above), 34, 58 - 62, 91 - 4.

${ }^{20}$ Ibid, $58-62$.

${ }^{21}$ Ibid, 16 - 19, 82 - 91. Longerich (see note 10 above), 184 - 201.

${ }^{22}$ Kershaw (see note 5 above), 499 - 505 .

${ }^{23}$ Ian Kershaw, Hitler, 1936- 45: Nemesis (New York: W. W. Norton, 2000), 424 - 5, 449.

${ }^{24}$ Dams and Stolle (see note 5 above), 69 - 71.

25 Kershaw (see note 5 above), 505.

${ }^{26}$ Dennis Showalter, Armor and Blood: the Battle of Kursk, the Turning Point of World War II (New York: Random House, 2013), 53, $103-4$.

27 Alan Clark, Barbarossa: the Russian- German Conflict, 1941- 1945 (New York: Quill, 1985), 182- 92.

${ }^{28}$ Kershaw (see note 23 above), $651-84$.

${ }^{29}$ Dams and Stolle (see note 5 above), 63 - 4.

30 Ortega y Gasset (see note 1 above), 57 - 63.

31 Ibid, $120-21$.

32 Bruce Schneier, Data and Goliath: The Hidden Battles to Collect Your Data and Control Your World (New York: W. W. Norton, 2015), 13.

${ }^{33}$ Ibid, 18.

${ }^{34}$ Ibid, 29.

${ }^{35}$ Ibid, $119-20$.

36 Ibid, 64.

37 Ibid, 40 - 2. 
38 Julia Angwin, Dragnet Nation: A quest for privacy, security, and freedom in a world of relentless surveillance (New York: Henry Holt, 2014), 1 - 20.

${ }^{39}$ Schneier (see note 32 above), 42 .

40 'A government snoop that puts the NSA to shame', Wall Street Journal, 2 July 2015.

${ }^{41}$ Mario Vargas Llosa, Notes On The Death Of Culture: Essays on Spectacle and Society (New York: Farrar, Straus and Giraux, 2012).

42 Ibid, 23 - 56.

${ }^{43}$ Babbitt (see note 4 above), 110. 